\title{
Author Correction: The importance of Antarctic krill in biogeochemical cycles
}

\author{
E.L. Cavan, A. Belcher (1), A. Atkinson (1D, S.L. Hill (1), S. Kawaguchi, S. McCormack (D, B. Meyer, S. Nicol, \\ L. Ratnarajah, K. Schmidt (D), D.K. Steinberg, G.A. Tarling \& P.W. Boyd
}

Correction to: Nature Communications https://doi.org/10.1038/s41467-019-12668-7, published online 18 October 2019.

The original version of this Article included an incorrect competing interests statement, which read 'The authors declare no competing interests', rather than the correct 'The authors declare the following competing interest: Steve Nicol has been employed to provide scientific advice to the Association of Responsible Krill harvesting companies.' This has been corrected in both the PDF and HTML versions of the Article.

Published online: 20 November 2019

\begin{abstract}
(c) Open Access This article is licensed under a Creative Commons Attribution 4.0 International License, which permits use, sharing, adaptation, distribution and reproduction in any medium or format, as long as you give appropriate credit to the original author(s) and the source, provide a link to the Creative Commons license, and indicate if changes were made. The images or other third party material in this article are included in the article's Creative Commons license, unless indicated otherwise in a credit line to the material. If material is not included in the article's Creative Commons license and your intended use is not permitted by statutory regulation or exceeds the permitted use, you will need to obtain permission directly from the copyright holder. To view a copy of this license, visit http://creativecommons.org/licenses/by/4.0/.
\end{abstract}

(C) The Author(s) 2019 